\title{
Characterization of Ground SBR Scraps from Shoe Industry
}

\author{
Marinês Massarotto, Janaina da Silva Crespo, Ademir José Zattera, Mara Zeni* \\ Departamento de Física e Química e Departamento Engenharia Química, PGMAT \\ Universidade de Caxias do Sul-UCS, \\ CP 1352, 95070-560 Caxias do Sul - RS, Brazil
}

Received: August 29, 2007; Revised: February 4, 2008

\begin{abstract}
Expanded poly(butadiene-co-styrene) (SBR), a residue of the shoe industry of Rio Grande do Sul, is a crosslinked material. For further utilization in recycling and reclaiming processes this residue was ground under ambient conditions. The obtained powder (SBR-r) was physically, thermally and chemically characterized and the results were analyzed as for its suitability for reuse methods. This characterization provides a better understanding of the SBR residue components, which may lead to economic and environmental advantages. The SBR-r (35-48 mesh) is composed by $22.2 \%$ of SBR and $77.8 \%$ of filler. The elastomeric fraction has $71.4 \%$ of crosslinked material. The results demonstrate that SBR can be recycled for use in microcellular composites.
\end{abstract}

Keywords: SBR residue, grinding, characterization

\section{Introduction}

The recycling of residues in the form of materials for different applications has provided an alternative solution for several problems related to environmental issues, both in terms of the reduction in the volume of residues generated and their discharge hazards, and the decrease in the use of increasingly scarce natural resources.

In this context lies the shoe industry in which, with the development of petrochemistry and with the appearance of synthetic materials, alternative raw materials began to be used ${ }^{1}$, reflected in an increase in the generation of wastes which are difficult to degrade in the production process and post consumption. According to data from Fundação Estadual de Proteção Ambiental (State Foundation for Environmental Protection), FEPAM, the shoe industry is responsible for $23 \%$ of the solid waste generated in the state of Rio Grande do Sul (RS) ${ }^{2}$. Studies carried out in 2001 by Serrano et al. ${ }^{3}$ showed that the shoe sector in the region of Vale do Rio dos Sinos, RS/ Brazil, generated a quantity of polymeric residues over 180 t.mth ${ }^{-1}$, poly (butadiene-co-styrene) (SBR) being in the greatest quantity $(25.1 \%)$.

Of the types of polymeric materials, rubbers or elastomers have their own unique characteristics. They have elasticity, which is the capacity to allow great deformation under low tension and, on removing the tension, return almost immediately to the initial condition, without significant loss of shape and dimensions, in a reversible process ${ }^{4}$. According to statistics from the International Rubber Study Group, the world consumption of natural and synthetic rubber in 2005 was 20.7 million tonnes ${ }^{5}$. With technological progress in the recycling area, rubber residues are seen as a valuable raw material for other applications, such as: strengthening/filling materials; incorporation into asphalt; flooring for leisure and recreation areas; among others.

The nature of rubber residues generates great environmental problems, since its natural degradation occurs over long time periods due to the presence of cross-linking in its structure and of stabilizers and other additives. The solution to minimize this problem is the recycling and recovery in new materials ${ }^{6-8}$.

Landfills were the first means of disposal of rubber residues. This alternative is expensive since it involves a high cost of transport of material to the site and the maintenance of the landfill under adequate conditions. It must also be considered that during the decomposition of rubber, many of the additives decompose quickly and migrate to the surface of the landfill, causing serious environmental problems ${ }^{9}$.

According to Adhikari et al. ${ }^{9}$ in general, low quantities of residues can be added to virgin rubber without significant changes in its properties occurring. In some cases the filler can act as a support material improving the properties, depending on the type of residue and the process used ${ }^{9-12}$.

The residues used in this study are expanded SBR chips, generated during the operation of cutting insoles, which are not used in the production process. The chips are sent to the Central de Resíduos do Sindicato das Indústrias Calçadistas de Três Coroas, (Waste Center of the Shoe Industry Union of Três Coroas), RS, in duly identified packs.

The objective of this study is the obtention and characterization of SBR-r powder, aiming at a later application in a mixture with virgin $\mathrm{SBR}$, in order to obtain cellular composites.

\section{Experimental}

\subsection{Sample grinding}

The SBR was ground in a Seibt AS/30/500 agglutinator $(25 \mathrm{~kg}$; time $=5$ minutes; rotation $=285 \mathrm{rpm}$ ) at room temperature and homogenized by wheel blasting $25 \mathrm{~kg}$ of SBR were ground and stored.

\subsection{Sample characterization}

The powder obtained in the previously described process, SBR-r, was characterized by physical, thermal and chemical methods ${ }^{13}$.

\subsection{Physical characterization}

The particle size determination was carried out according to the norm ASTM D 5644-96, using a Produtest sieve and a set of sieves normalized by the Brazilian Association of Technical Norms (Associação Brasileira de Normas Técnicas - ABNT) by means of EB-22. 
The scanning electron microscopy (SEM) was carried out with a Philips XL 30 scanning electron microscope. The sample was metallized in a P-S2 DIODE Sputtering System metallizer. The qualitative analysis of the fillers was carried out in an energy-dispersive spectrometer (EDS) coupling at SEM.

\subsection{Thermal characterization}

The thermal degradation was carried out by thermogravimetric analysis (TGA) in a Shimadzu TGA-50, with a nitrogen flow of $50 \mathrm{~mL} / \mathrm{min}$, from ambient temperature up to $800{ }^{\circ} \mathrm{C}$, with a heating rate of $10^{\circ} \mathrm{C} / \mathrm{min}$. The differential scanning calorimetry (DSC) was carried out using a Shimadzu DSC-50, under a nitrogen flow, from $-100{ }^{\circ} \mathrm{C}$ up to $250{ }^{\circ} \mathrm{C}$, with heating rate of $10{ }^{\circ} \mathrm{C} / \mathrm{min}$.

\subsection{Chemical characterization}

The determination of gel content was carried out in triplicate, by extraction in Soxhlet with toluene, using $1 \mathrm{~g}$ of sample, for 24 hours according to the norm ASTM D 3616-95. The residue was then removed and dried at $60{ }^{\circ} \mathrm{C}$, under vacuum, for approximately 6 hours.

\section{Results and Discussion}

\subsection{Physical characterization}

In the granulometric analysis, Table 1 , it was verified that the ground residue had an average particle size between 35 and 48 mesh $(0.425$ and $0.30 \mathrm{~mm})$. According to the literature, the particle size of the rubber powder to be added to virgin rubber must be less than $0.60 \mathrm{~mm}$ to achieve a better incorporation ${ }^{14}$. Thus, the grinding was effective, producing a powder adequate for incorporation into virgin material.

The micrographs of SBR-r are shown in Figure 1. The micrographs indicate the heterogeneous granulometry of the residue, Figure $1 \mathrm{a}$ and $1 \mathrm{~b}$, as observed in the granulometric analysis. The presence of fillers in the power was also verified (Figure 1c), corroborating the TGA analysis. The qualitative analysis of the fillers, indicated the presence of calcium $\left(\mathrm{CaCO}_{3}\right)$, silica $\left(\mathrm{SiO}_{2}\right)$ and magnesium (talc) $\mathrm{Mg}_{3} \mathrm{H}_{2} \mathrm{Si}_{4} \mathrm{O}_{12}$, which are common in this type of material.

\subsection{Thermal characterization}

The TGA allowed the identification of sample mass loss as a function of temperature in a controlled atmosphere. The mass loss below $300{ }^{\circ} \mathrm{C}$ refers to the presence of volatile agents such as plasticizers and antioxidants. The mass loss between 300 and $600{ }^{\circ} \mathrm{C}$ corresponds to the polymeric content. The mass loss between 600 and $950^{\circ} \mathrm{C}$ relates to inorganic additives, pigments or metal oxides ${ }^{14}$.

In the TGA of the SBR-r, two mass loss stages were observed (Figure 2). The first loss was of approximately $22.2 \%$ in the range of 390 to $445^{\circ} \mathrm{C}$, corresponding to the elastomer. The second loss of

Table 1. Particle size of SBR-r powder.

\begin{tabular}{|c|c|c|}
\hline \multicolumn{2}{|c|}{ Sieve size } & \multirow[t]{2}{*}{ Retained (\%) } \\
\hline (mesh) & $(\mathrm{mm})$ & \\
\hline 24 & 0.71 & $6.10 \pm 0.30$ \\
\hline 28 & 0.60 & $11.4 \pm 0.66$ \\
\hline 35 & 0.43 & $34.7 \pm 0.40$ \\
\hline 48 & 0.30 & $20.4 \pm 0.61$ \\
\hline 65 & 0.21 & $14.2 \pm 0.44$ \\
\hline 100 & 0.15 & $6.70 \pm 0.46$ \\
\hline$<100$ & $<0.15$ & $3.30 \pm 1.29$ \\
\hline
\end{tabular}

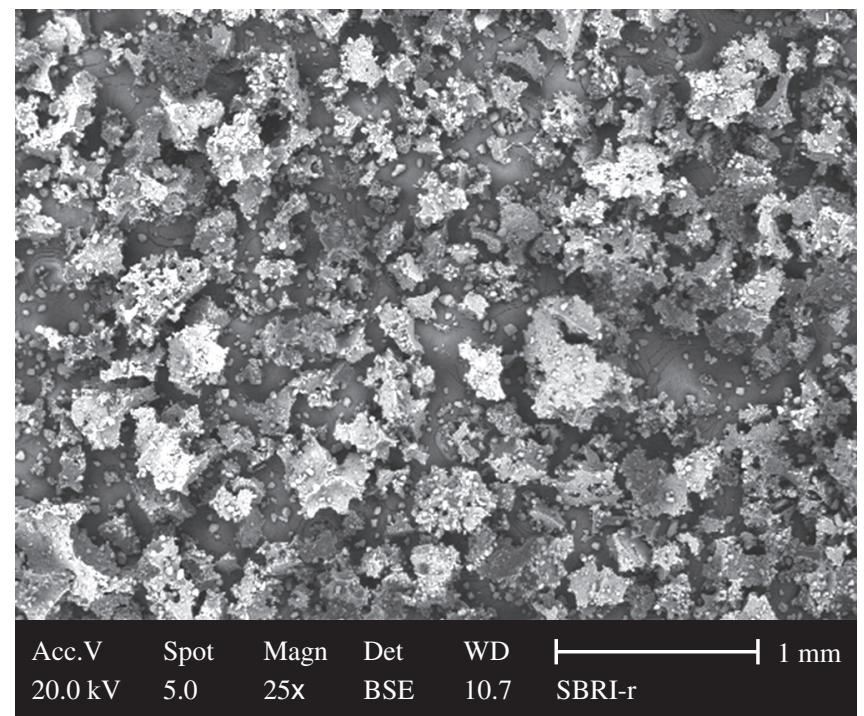

(a)

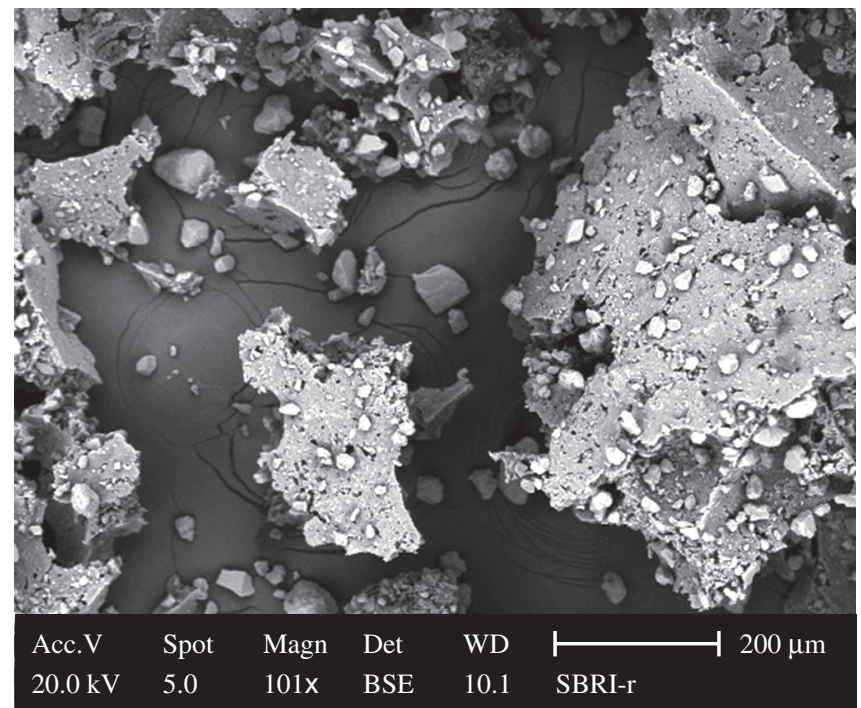

(b)

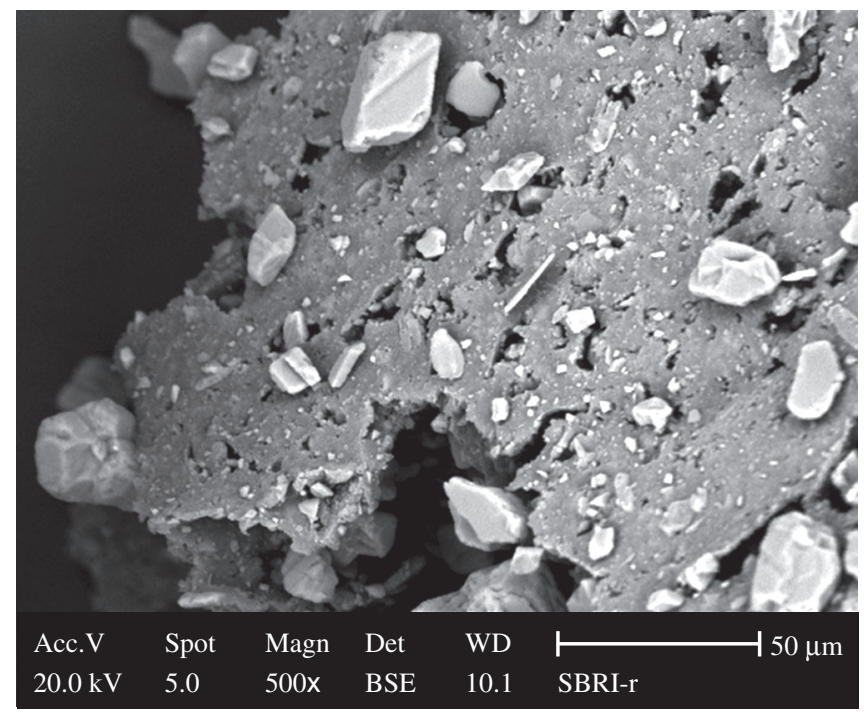

(c)

Figure 1. Micrographs of the SBR residue a) magnification of $25 x$; b) magnification of $100 \mathrm{x}$ and c) magnification of 500x. 
$30.1 \%$ at $726^{\circ} \mathrm{C}$, corresponds to the loss of $\mathrm{CO}_{2}$ due to the thermal decomposition of $\mathrm{CaCO}_{3}$. The residual mass at $800{ }^{\circ} \mathrm{C}$ was $47.7 \%$. Thus, the residue has $22.2 \%$ of SBR and $77.8 \%$ of filler.

In Figure 3, DSC thermograms of SBR-r is shown. The DSC thermogram of SBR-r showed the presence of a Tg (glass transition temperature) of the material at $-43.93{ }^{\circ} \mathrm{C}$. The Tg value of SBR-r is very close to the $\mathrm{Tg}$ for virgin $\mathrm{SBR}\left(-48^{\circ} \mathrm{C}\right)^{4}$. There is no exothermic peak in the region of $200{ }^{\circ} \mathrm{C}$, showing that the amount of residual accelerators and/or sulfur is not sufficient to cause sample vulcanization. The absence of this exothermic peak can also be explained by the natural heating of the samples that occurs during the grinding process. It is possible that during grinding there was further sample vulcanization, since industrial and not post-consumption scraps were utilized.

\subsection{Chemical characterization}

The gel fraction of the SBR-r was calculated based on Equations 1 and $2^{15}$.

$$
\% \text { extraction ofpolymeric material }=\frac{\% \mathrm{M}_{\text {extracted }}}{100-\% \mathrm{M}_{\text {residual }}} \mathrm{X} 100
$$

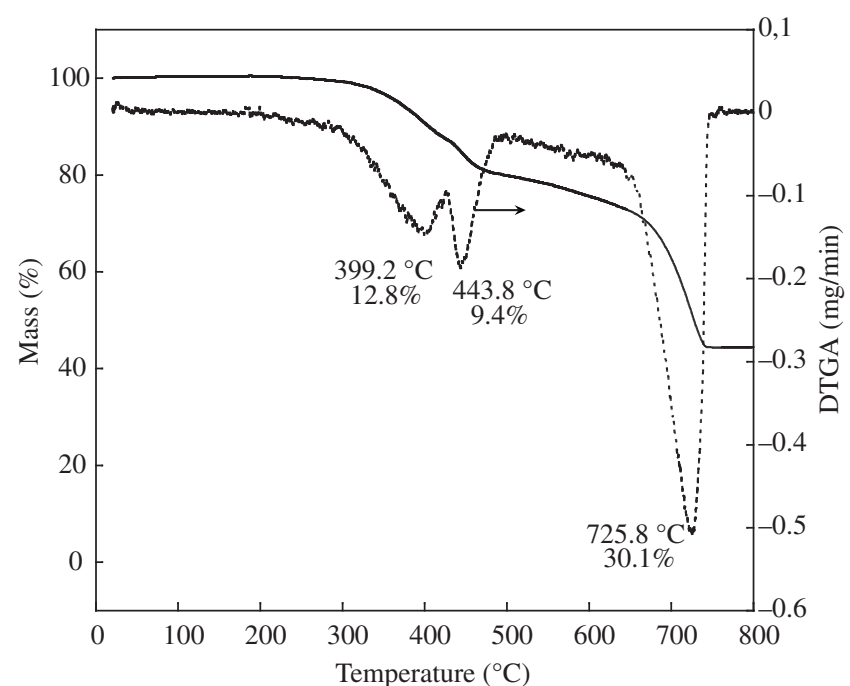

Figure 2. TGA thermogram of SBR-r $\left(\mathrm{N}_{2}\right.$ flow of $50 \mathrm{~mL} / \mathrm{min}$ with a heating rate of $10^{\circ} \mathrm{C} / \mathrm{min}$ )

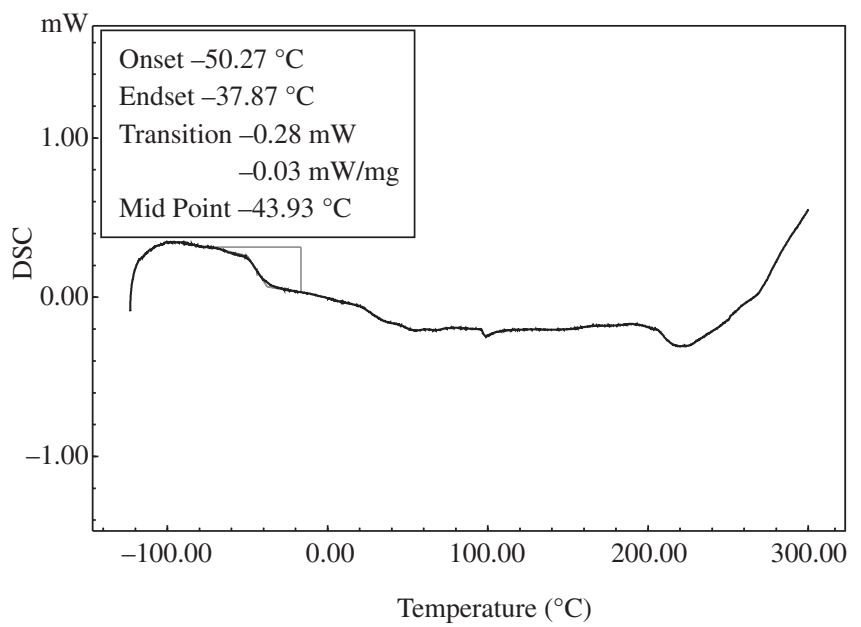

Figure 3. DSC thermogram of SBR-r $\left(\mathrm{N}_{2}\right.$ flow of $50 \mathrm{~mL} / \mathrm{min}$ with a heating rate of $10^{\circ} \mathrm{C} / \mathrm{min}$ )
Gel content $=[100-(\%$ extraction of polymeric material $)]$ where, $\mathbf{M}_{\text {extracted }}$ is the percentage mass extracted in the gel determination test;

$\mathrm{M}_{\text {residual }}$ is the residual percentage mass obtained in the TGA analysis.

Thus, the SBR-r had $71.4 \%$ of reticulated material and $28.6 \%$ of soluble material (relating to the $22.2 \%$ of rubber present in SBR-r, determined by TGA).

\section{Conclusions}

From the results obtained it was possible to verify that the grinding of SBR residue was effective, producing a powder adequate for use in virgin SBR mixtures, with the aim of later application in the obtention of SBR foams.

Through the thermogravimetric analysis it was possible to observe that the residue is composed by $22.2 \%$ of SBR and $77.8 \%$ of fillers.

On evaluating the SEM micrographs, a heterogeneous granulometry of the residue was verified, with the presence of fillers in the rubber powder.

\section{Acknowledgments}

The authors wish to thank the Sindicato das Indústrias Calçadistas de Três Coroas-RS, (Shoe Industry Union of Três Coroas-RS), CNPq, FAPERGS/Procoredes II (Case No. 0518831) for financial support; to CIAFLEX Indústria de Borrachas Ltda. for supplying the chemicals reactivs; and UCS for the support in the development of this study.

\section{References}

1. Andrade JEP, Correa AR, Panorama da Indústria Mundial de Calçados, com Ênfase na América Latina, in BNDES Setorial report issue, Rio de Janeiro, RJ, Brazil, 2001.

2. Geração de Resíduos Sólidos Industriais no RS, Comission reported, Porto Alegre-RS; Brazil, Avaliable from: http://www.fepam.rs.gov.br/ biblioteca/rsi.asp.htm. [in 2006 August].

3. Serrano CLR, Da Silva IF. Mapeamento dos resíduos poliméricos produzidos pela indústria calçadista na região do Vale do Rio do Sinos. In: $6^{\circ}$ Congresso Brasileiro de Polímeros, Issue; Gramado-RS, Brazil. 2001; (1): 1796-1799.

4. Mano EB, Mendes LC. Introdução a Polímeros, $2^{\mathrm{a}}$ Ed.; Edgar Blücher Ltda, Rio de Janeiro, RJ, 1999; (1).

5. Internacional Rubber Study Group, N.Y.-USA. Avaliable from: http://www.rubberstudy.com. [in 2006 May].

6. Guerra BB, Furtado CRG. Coutinho FMB., Avaliação reológica de elastômeros e suas composições, Polímeros: Ciência e Tecnologia. 2004; 14(4): 289-294.

7. Tripathy AR, Morin JE, Willians E, Eyles SJ, Farris RJ. A novel approach to improving the mechanical properties in recycled vulcanizes natural rubber and its mechanism, Macromolecules. 2002; 35(12): 4616-4627.

8. Fang Y, Zhan M, Wan Y. The status of recycling of waste rubber, Materials and Design. 2001; 22(2): 123-127.

9. Adhikari B, Mait D, De S. Reclamation and recycling of wate rubber, Progress in Polymer Science. 2000; 25(4): 909-948.

10. Myhre M, Mackillop DA. Rubber recycling, Rubber Chemistry and Technology, 2002; 75(2): 429-434.

11. Papautsky D. Borracha Recuperação e Regeneração. Avalilable from: http://www.borrachaatual.com.br/matériastécnicas/borracharecuperação e regeneração.ht. [in 2006 April ]. 
12. Gibala D, Hamed GR. Cure and mechanical behavior of rubber compounds containing ground vulcanizates - Parte I - Cure behavior, Rubber Chemistry and Technology, 1997; 67(1):636-648.

13. Bilgili E, Arastoopour H, Bernestein B. Pulverization of rubber granulates using the solid state shear extrusion process Parte II - powder characterization, Powder Technology. 2001; 115(2):277-89.
14. Nagdi K. Rubber as an Engineering Material: guideline for users., $1^{\mathrm{a}} \mathrm{Ed}$. Munich, Vienna; MunichHanser Publishers, 1993.

15. Zattera AJ, Bianchi O, Zeni M, Ferreira CA. Caracterização de Resíduos de Copolímeros de Etileno-Acetato de Vinila - EVA, Polímeros: Ciência e Tecnologia, 2005; 15(1):73-78. 